\title{
MENINGKATKAN KEMAMPUAN MENULIS PUISI MELALUI METODE KARYA WISATA
}

\author{
IImal Yaqien \\ STMIK Mataram \\ il.ayyato87@gmail.com
}

\begin{abstract}
Abstrak: Tujuan penelitian ini secara umum untuk mendeskripsikan apakah metode karya wisata dapat meningkatkan kemampuan menulis puisi siswa. Sedangkan tujuan khususnya adalah untuk memberikan nuansa baru bagi siswa agar tidak merasa jenuh dan lebih mudah mendapatkan imajinasi dalam mengeksplorasi kompetensinya dalam menulis puisi, sehingga mereka memperoleh pengalaman yang menyenangkan. Hasil penelitian dapat terlihat ditiap aspek puisi. Hal ini terbukti dengan hasil tiap-tiap aspek dari perolehan rata-rata tiap aspek puisi. Yakni Rima pada prasiklus nilai rata-rata 2,5, sedang pada siklus I 3,4, dan pada siklus II meningkat menjadi 4,1 sehingga memperoleh peningkatan sebesar $64,00 \%$. Untuk Aspek Bait pada prasiklus nilai rata-rata 2,7, sedang pada siklus I 3,1 , dan pada siklus II meningkat menjadi 4,2 sehingga memperoleh peningkatan sebesar $55,56 \%$. Sedang untuk aspek irama prasiklus nilai rata-rata 2,5, sedang pada siklus I 3,1 , dan pada siklus II meningkat menjadi 4,2 sehingga memperoleh peningkatan sebesar $68,00 \%$. Sementara untuk ratarata kelas mengalami peningkatan dari prasiklus kesiklus I sebesar $24,9 \%$, untuk siklus I kesiklus II $30,5 \%$, dan untuk prasiklus ke siklus II 62,5\%. Data tersebut menunjukkan peningkatan hasil tes keterampilan menulis puisi prasiklus, siklus I, dan Siklus II. Serta peningkatan pada aspek yang diujikan dalam keterampilan menulis puisi. Hasil tes menulis puisi pada prasiklus dan siklus I menunjukkan hasil yang kurang memuaskan karena tidak mencapai pada target yang telah ditentukan. Akan tetapi pada siklus II hasil tes menulis puisi sudah memuaskan dan patut dibanggakan karena telah mencapai target yang telah ditentukan. Nilai rata-rata pada siklus II yaitu 81,27 atau diatas dari nilai rata-rata yang ditargetkan. Berdasarkan hasil analisis dan pembahasan, penelitian ini dapat disimpulkan, pembelajaran menulis puisi dengan metode karya wisata berhasil meningkatkan keterampilan siswa dalam menulis puisi. Hal ini membuktikan adanya perubahan perilaku yang positif melalui pemahaman siswa terhadap materi pembelajaran menulis puisi.
\end{abstract}

\section{Kata kunci: keterampilan menulis, puisi, metode karya wisata}

\section{Latar Belakang}

Keterampilam menulis merupakan salah satu dari empat keterampilan berbahasa yaitu menyimak, membaca, menulis dan berbicara. Diantara empat keterampilan berbahasa ini, keterampilan menulis adalah yang menjadi bahan penelitian dengan pertimbangan keterampilan menulis merupakan keterampilan yang bersifat aktif produktif. Keterampilan ini dipandang menduduki hierarki yang paling rumit dan kompleks di antara jenis-jenis keterampilan berbahasa lainnya. Selanjutnya, seseorang dikatakan memiliki keterampilan menulis bila yang bersangkutan dapat memilih bentuk-bentuk bahasa tertulis (berupa kata, kalimat, paragraf) serta menggunakan retorika (organisasi tulisan) yang tepat guna mengutarakan pikiran, perasaan, gagasan, fakta. Aktivitas menulis bukan hanya sekedar menyalin kata-kata dan kalimat-kalimat; melainkan menuangkan dan mengembangkan pikiran-pikiran, gagasan, ide, dalam struktur tulisan yang teratur, logis, sistematis, sehingga dapat dipahami penikmat atau pembaca.

Adapun upaya peningkatan keterampilan menulis di sekolah dapat dilaksanakan melalui berbagai kegiatan, di antaranya menulis artikel, menulis karya ilmiah, menulis cerpen, menulis naskah drama, menulis puisi, dan lain sebagainya. Lebih-lebih lagi ketika dibenturkan dengan menulis puisi yang memang bagian dari Language Art dalam sastra yaitu dengan mempertimbangkan dalam merangkai katakata yang bersifat estetis, menentukan diksi, sampai kepada minat siswa yang kurang dalam belajar puisi. Selain dari factor siswa, ternyata memang ada juga dari pengajar yang kurang memperhatikan bakat dan minat siswa dari segi metode pembelajaran, media yang kurang menarik, bahkan cenderung monoton dengan ceramah. Hal inilah yang menjadi pertimbangan dari peneliti untuk mengangkat tema ini untuk dikaji secara komperhensif dalam menghadirkan strategi yang bisa merangsang siswa tidak kaku, tidak jenuh, dan lebih mempertajam daya fantasi yang dibangun untuk meningkatkan kemampuan memahami dan meningkatkan ide, kualitas proses belajar dan hasil belajar siswa melalui kegiatan wisata.

\section{Kajian Pustaka}




\section{A. Menulis \\ a. Pengertian menulis}

Menulis merupakan suatu proses kreatif memindahkan gagasan ke dalam lambang lambang tulisan, dalam pengertian ini, menulis memiliki tiga asfek utama, yaitu : (a) adanya tujuan atau maksud tertentu yang ingin dicapai, (b) adanya gagasan yang hendak dikomunikasikan, (c) adanya sistem pemindahan gagasan berupa sistem bahasa (Tarigan 2008 : 16). Nugiantoro (2001:298) berpendapat menulis adalah "aktivitas aktif -produtif, aktivitas menghasilkan bahasa. Dilihat dari pengertian secara umum, menulis adalah aktivitas mengemukakan gagasan melalui media bahasa. Aktivitas yang pertama menekankan unsur bahasa, sedang yang kedua gagasan".

Kemudian ditegaskan lagi oleh Gie dan Wiyanto dalam Mustakim (2008:7) menyatakan bahwa mengarang atau menulis adalah segenap rangkaian kegiatan seseorang mengungkapkan gagasan dan menyampaikannya melalui bahasa tulis kepada masyarakat pembaca untuk dipahami. Melalui bahasa tulis, penulis atau pengarang berusaha mengungkapkan ide-idenya agar dipahami pembaca. selanjutnya menulis mempunyai dua kegiatan utama. Kegiatan yang pertama adalah mengubah bunyi yang dapat didengar menjadi tanda-tanda yang dapat dilihat, sedangkan yang kedua kegiatan mengungkapkan gagasan secara tertulis. Orang yang melakukan kegiatan ini dinamakan penulis dan hasil kegiatannya berupa tulisan. Lanjut Gie (2001: 25-30) mengelompokkan tulisan atas beberapa kriteria, salah satu kriterianya adalah berdasarkan ragamnya, yakni; tulisan faktawi (faktual) dan tulisan khayali (imajinasi).

Begitu juga selanjutnya Tarigan (2008:3) mengemukakan bahwa menulis pada hakikatnya merupakan suatu keterampilan berbahasa yang dipergunakan untuk berkomunikasi secara tidak langsung, tidak secara tatap muka dengan orang lain. Menulis merupakan suatu kegiatan yang produktif dan aktif. Keterampilan menulis perlu ditanamkan kepada siswa di sekolah sehingga mereka mampu menuangkan ide, gagasan, pikiran dan pendapat dengan baik.

Sebagaimana pemaparan dari beberapa ahli diatas dapat diartikan bahwa menulis merupakan aktifitas mengeksplorasi ide atau gagasan yang kemudian dituangkan dalam bentuk media tulis agar bisa dinikmati oleh pembaca.

\section{b. Manfaat danTujuan Menulis}

Enre (1988:6), menegaskan manfaat menulis yaitu:

1. menulis menolong kita menemukan kembali apa yang pernah kita ketahui

2. menulis menghasilkan ide-ide baru

3. menulis membantu mengorganisasikan pikiran kita

4. menulis menjadikan pikiran seseorang siap untuk dilihat dan dievaluasi

5. menulis membantu kita menyerap dan menguasai informasi baru

6. menulis membantu kita memecahkan masalah

Sedangkan Horiston mengatakan manfaat menulis dalam Darmadi (1996:3-4), yaitu:

1) kegiatan menulis adalah sarana untuk menemukan sesuatu, dalam artian dapat mengangkat ide dan informasi yang ada di alam bawah sadar pemikiran kita. 2) kegiatan menulis dapat memunculkan ide baru. 3) kegiatan menulis dapat melatih kemampuan mengorganisasi dan menjernihkan berbagai konsep atau ide yang kita milki. 4) kegiatan menulis dapat melatih sikap objektif yang ada pada diri seseorang. 5) kegiatan menulis dapat membantu diri kita untuk berlatih memecahkan beberapa masalah sekaligus. 6) kegiatan menulis dalam sebuah bidang ilmu akan memungkinkan kita untuk menjadi aktif dan tidak hanya menjadi penerima informasi.

Berdasarkan beberapa pendapat di atas, dapat simpulkan bahwa manfaat menulis adalah dapat memunculkan ide baru, membantu mengorganisasikan pikiran, dan membantu memecahkan masalah. Dalam penelitian ini, manfaat yang ingin diperoleh siswa pada kegiatan menulis puisi adalah memunculkan ide baru dalam mengungkapkan gagasannya ke dalam bentuk puisi.

Sedangkan tujuan dari menulis adalah agar tulisan yang dibuat dapat dibaca dan dipahami dengan benar oleh orang lain yang mempunyai kesamaan pengertian terhadap bahasa yang dipergunakan. Sedangkan menurut Suparno dan Mohamad Yunus (2008: 3.7), tujuan yang ingin dicapai seorang penulis bermacam-macam sebagai berikut.

a) Menjadikan pembaca ikut berpikir dan bernalar.

b) Membuat pembaca tahu tentang hal yang diberitakan.

c) Menjadikan pembaca beropini.

d) Menjadikan pembaca mengerti.

e) Membuat pembaca terpersuasi oleh isi karangan.

f) Membuat pembaca senang dengan 
menghayati nilai-nilai yang dikemukakan seperti nilai kebenaran, nilai agama, nilai pendidikan, nilai sosial, nilai moral, nilai kemanusiaan dan nilai estetika.

\section{B. Puisi}

Pradopo (2002:7) menyatakan bahwa puisi itu mengekspresikan pemikiran yang membangkitkan perasaan yang merangsang imajinasi pancaindra dalam susunan berirama. Semua itu merupakan suatu yang penting yang direkam dan diekspresikan, dinyatakan dengan menarik dan memberi kesan.

Selanjutnya Puisi adalah sebuah genre sastra yang amat memperhatikan pemilihan aspek kebahasaan sehingga tidak salah jika dikatakan bahasa puisi adalah bahasa yang 'tersaring' penggunaannya. Artinya, pemilihan bahasa itu, terutama aspek diksi, telah melewati seleksi ketat, dipertimbangkan dari berbagai sisi baik yang menyangkut unsur bunyi, bentuk dan makna yang kesemuanya harus memenuhi persyaratan memperoleh efek keindahan (Nurgiyantoro dalam Pranoto, 2008:13).

Sedangkan Suharianto (2005:12) mengungkapkan puisi adalah hasil pengungkapkan kembali segala peristiwa atau kejadian yang terdapat pada kehidupan seharihari. Begitu juga Waluyo (2002:1) mengemukakan puisi adalah karya sastra dengan bahasa yang dipadatkan, dipersingkat, dan diberi irama dengan bunyi yang padu dan pemilihan kata-kata kias (imajinatif).

Dari pandangan-pandangan ahli diatas dapat ditarik benang merah bahwa puisi merupakan bagian dari alat ekspresi diri yang masuk kedalam genre sastra dengan memperhatikan aspek kebahasaan dan bersifat imajinatif atas hasil pengungkapan terhadap segala peristiwa yang pernah terjadi.

\section{Metode Karya Wisata}

Metode karyawisata adalah metode pembelajaran yang mengajak siswa untuk mengunjungi obyek-obyek dalam rangka untum menambah dan memperluas wawasan obyek yang dipelajari tersebut ( sesuai dengan bidangnya). Misalnya untuk pelajaran pendidikan geografi siswa dapat diajak ke obyek pemukiman transmigrasi atau obyek morfologi. Untuk pelajaran pendidikan sejarah, siswa dapat diajak ke situs sejarah. Untuk pelajaran pendidikan ekonomi siswa dapat diajak mengunjungi pabrik, atau obyek kegiatan ekonomi.

Karyawisata juga dapat dikatakan sebagai kegiatan perjalanan atau kunjungan lapangan adalah suatu perjalanan oleh sekelompok orang ke tempat yang jauh dari lingkungan normal. Tujuan perjalanan biasanya pengamatan untuk pendidikan, noneksperimental penelitian atau untuk memberikan pengalaman siswa di luar kegiatan sehari-hari mereka.

Adapun metode karyawisata menurut para ahli sebagai berikut

1) Menurut Roestiyah

Karya wisata bukan sekedar rekreasi, tetapi untuk belajar atau memperdalam pelajarannya dengan melihat kenyataannya. Karena itu dikatakan teknik karya wisata, ialah cara mengajar yang dilaksanakan dengan mengajak siswa ke suatu tempat atau obyek tertentu di luar sekolah untuk mempelajari atau menyelidiki sesuatu seperti meninjau pabrik sepatu, suatu bengkel mobil, toko serba ada, dan sebagainya.

\section{2) Menurut checep}

Metode karyawisata atau widyawisata adalah cara penyajian dengan membawa siswa mempelajari materi pelajaran di luar kelas. Karyawisata memanfaatkan lingkungan sebagai sumber belajar, dapat merangsang kreativitas siswa, informasi dapat lebih luas dan aktual, siswa dapat mencari dan mengolah sendiri informasi. Tetapi karyawisata memerlukan waktu yang panjang dan biaya, memerlukan perencanaan dan persiapan yang tidak sebentar.

\section{3) Menurut Mulyasa}

Metode field trip atau karya wisata merupakan suatu perjalanan atau pesiar yang dilakukan oleh peserta didik untuk memperoleh pengalaman belajar, terutama pengalaman langsung dan merupakan bagian integral dari kurikulum sekolah. Meskipun karya wisata memiliki banyak hal yang bersifat non akademis, tujuan umum pendidikan dapat segera dicapai, terutama berkaitan dengan pengembangan wawasan pengalaman tentang dunia luar.

\section{4) Menurut Djamarah.}

Teknik karya wisata, yang merupakan cara mengajar yang dilaksanakan dengan mengajak siswa ke suatu tempat atau obyek tertentu di luar sekolah untuk mempelajari atau menyelidiki sesuatu seperti meninjau pegadaian. Banyak istilah yang dipergunakan pada metode karya wisata ini, seperti widya wisata, study tour, dan sebagainya. Karya wisata ada yang dalam waktu singkat, dan ada 
pula yang dalam waktu beberapa hari atau waktu panjang (Supardiyanto, $2006: 17$ )

\section{Metode Penelitian}

Metode penelitian pada dasarnya merupakan cara ilmiah untuk mendapatkan data dengan tujuan dan kegunaan tertentu. Berdasarkan hal tersebut terdapat empat kata kunci yang perlu diperhatikan yaitu : cara, data, tujuan dan kegunaan.(Sugiono, $2009: 2$, cetakan 7). Penelitian ini adalah penelitian tindakan kelas. Desain penelitian tindakan kelas ini menggunakan desain Kemmis dan Taggart (dalam Madya 1994:24) yang merupakan bentuk kajian yang bersifat reflektif. Kajian dilaksanakan dengan maksud untuk meningkatkan kemantapan rasional dari tindakan-tindakan yang dilakukan serta memperbaiki kondisi-kondisi praktik pembelajaran sebelumnya. Sanjaya (2009:25) menjelaskan penelitian tindakan kelas adalah kajian tentang situasi sosial dengan maksud untuk meningkatkan kualitas tindakan melalui proses diagnosis, perencanaan, pelaksanaan, pemantauan, dan mempelajari pengaruh yang ditimbulkannya.

pembelajaran tersebut terbagi menjadi tiga tahapan yakni prasiklus, siklus I, dan siklus II. Siklus ini terdiri atas empat komponen, yaitu perencanaan, tindakan, pengamatan, dan refleksi. Keempat komponen tersebut di pandang sebagai satu siklus. Penelitian tindakan kelas ini diawali dengan pretes terlebih dahulu. Setelah mengetahui kondisi awal siswa, kemudian dilakukan tindakan siklus I sebagai upaya perbaikan. Tindakan siklus II agar terjadi peningkatan hasil siswa.

\section{Hasil}

Hasil penelitian dapat terlihat ditiap aspek puisi. Hal ini terbukti dengan hasil tiap-tiap aspek dari perolehan rata-rata tiap aspek puisi. Yakni Rima pada prasiklus nilai rata-rata 2,5, sedang pada siklus | 3,4 , dan pada siklus II meningkat menjadi 4,1 sehingga memperoleh peningkatan sebesar 64,00\%. Untuk Aspek Bait pada prasiklus nilai rata-rata 2,7, sedang pada siklus I 3,1, dan pada siklus II meningkat menjadi 4,2 sehingga memperoleh peningkatan sebesar $55,56 \%$. Sedang untuk aspek irama prasiklus nilai rata-rata 2,5, sedang pada siklus | 3,1, dan pada siklus I| meningkat menjadi 4,2 sehingga memperoleh peningkatan sebesar $68,00 \%$. Sementara untuk rata-rata kelas mengalami peningkatan dari prasiklus kesiklus I sebesar $24,9 \%$, untuk siklus I kesiklus II 30,5\%, dan untuk prasiklus ke siklus II 62,5\%. Data tersebut menunjukkan peningkatan hasil tes keterampilan menulis puisi prasiklus, siklus I, dan Siklus II. Serta peningkatan pada aspek yang diujikan dalam keterampilan menulis puisi. Hasil tes menulis puisi pada prasiklus dan siklus I menunjukkan hasil yang kurang memuaskan karena tidak mencapai pada target yang telah ditentukan. Akan tetapi pada siklus II hasil tes menulis puisi sudah memuaskan dan patut dibanggakan karena telah mencapai target yang telah ditentukan. Nilai rata-rata pada siklus II yaitu 81,27 atau diatas dari nilai ratarata yang ditargetkan.

\section{Kesimpulan}

Berdasarkan hasil analisis dan pembahasan, penelitian ini dapat disimpulkan, pembelajaran menulis puisi dengan metode karya wisata berhasil meningkatkan keterampilan siswa dalam menulis puisi. Hal ini membuktikan adanya perubahan perilaku yang positif melalui pemahaman siswa terhadap materi pembelajaran menulis puisi. Berikut simpulan hasil penelitian:

1) Terdapat peningkatan pada keterampilan menulis puisi siswa setelah dilakukan tindakan penelitian dengan menggunakan metode karya wisata. Peningkatan keterampilan menulis puisi tersebut diketahui dari hasil prasiklus, siklus I, dan Siklus II. Nilai rata-rata menulis puisi setelah dilakukan tindakan prasiklus mencapai 51.33 dengan kategori kurang. Pada siklus I, nilai rata-rata tersebut mengalami peningkatan sebesar $22.93 \%$ menjadi 63.00 atau berkategori cukup dan pada siklus II, nilai rata-rata juga mengalami peningkatan sebesar $29.01 \%$ menjadi 81.27 atau berkategori baik peningkatan ini juga terjadi pada semua aspek yang diujikan dalam menulis puisi.

2) Berdasarkan hasil data non tes pada siklus I dan siklus II, siswa merespon positif terhadap pembelajaran menulis puisi dengan metode karya wisata. Siswa merasa senang setelah mengikuti pembelajaran menulis puisi dengan metode karya wisata, dan ini terbukti dari adanya perubahan perilaku siswa kearah positif. Suasana belajar yang dulunya kurang kondusif sekarang berganti menjadi lebih kondusif, aktif dan dalam menulis puisi siswapun sudah mulai percaya diri dan sudah mulai memperhatikan unsur-unsur pembangun puisi. Siswa semakin aktif dan bersemangat dalam mengikuti pembelajaran.

\section{Daftar Rujukan}

Darmadi, K. (1996). Meningkatkan Kemampuan Menulis. 
Yogyakarta: Penerbit Andi.

Ekasari, Anisa Diyah.2014. Peningkatan Keterampilan Menulis Puisi Melalui Strategi Pikir Plus. https://journal.unnes.ac.id/sju/ind ex.php/jpbsi/article/view/3984 (23 Desember 2018)

Enre, Fachruddin Ambo. (1988). Dasardasar Keterampilan Menulis. Jakarta: Departemen Pendidikan dan Kebudayaan.

Nurgiantoro, B. (2001). Penilaian Dalam Pengajaran Bahasa dan Sastra. Yogyakarta: BPFE.

Pradopo, Rachmat Djoko. 2002. Pengkajian Puisi. Yogyakarta: Gadjah Mada University.

Pranoto, Indhu. 2008. Peningkatan Keterampilan Menulis Puisi dengan Metode Jaring Laba-Laba Siswa Kelas VII A SMP Negeri 38 Semarang. Skripsi. Universitas Negeri Semarang.
Sanjaya, Wina. (2009). Penelitian Tindakan Kelas. Jakarta: Kencana Prenada Media Group.

Sugiyono, 2009. Metodologi Penelitian Kuantitatif Kualitatif Dan $R \& D$. Bandung. Alfabata.

Suharianto, S. 2005. Dasar-Dasar Teori Sastra. Semarang: Rumah Indonesia.

Supardiyanto, Teguh. 2002. Penggunaan Metode Karya Wisata Dalam Upaya Meningkatkan Motivasi Belajar Siswa Pada Bidang Studi Agama Islam (Studi Kasus di SMP Padindi Kalideres Jakarta Barat). Skripsi. Jakarta : UIN Syarif Hidayatullah.

Tarigan, H. G. (2008). Menulis Sebagai Suatu Keterampilan Berbahasa.Bandung: Angkasa.

Waluyo, Herman J. 1991. Teori Dan Apresiasi Puisi. Jakarta: Erlangga. 